\title{
PENDIDIKAN PENANAMAN SISTEM NILAI DALAM PEMBELAJARAN AQIDAH AKHLAQ
}

\author{
Mubasyaroh \\ STAIN Kudus, Jawa Tengah, Indonesia. \\ mubasyaroh@gmail.com
}

\begin{abstract}
Abstrak
Tulisan ini mengkaji tentang nilai-nilai yang terdapat dalam pembelajaran aqidah akhlaq. Desain pembelajaran yang digunakan adalah desain penulisan telaah pustaka. Jenis data dalam kajian ini adalah literatur yang terkait dengan tema kajian. Islam berkaitan dengan pendidikan spiritual dan membersihkan jiwa dari kejahatan, kebohongan, kemunafikan, dan prasangka terhadap seseorang tanpa sebab. Dalam pendidikan formal, guru menjadi mentor siswa dalam memiliki akhlakul karimah, dengan menjadi model peran yang baik. Hasil kajian ini menunjukkan bahwa sumber utama dalam penanaman sistem nilai selain AlQur'an dan Al-Sunnah yaitu nilai duniawi, pikiran, adat istiadat dan kenyataan alam.
\end{abstract}

Kata kunci: internalisasi, sistem, nilai, aqidah, pembelajaran, moralitas

\begin{abstract}
THE EDUCATION OF GROWING VALUED SYSTEM IN AQIDAH AKHLAQ LEARNING. This article examines the values contained int the aqidah akhlaq learning. The design oh this study is library research. The data of this study are literatures which relates with the topic. Islam is concerned with the spiritual education and cleanse the soul from malice, deceit, hypocrisy, and prejudice against someone without cause. In formal education, the teacher becomes the students' mentor in having akhlakul karimah, by being good role models. The
\end{abstract}


results of this study showed that the main sources in the growing valued system except Al-Qur'an and Al-Sunnah are worldly values, thoughts, customs, and the reality of nature.

Keywords: valued, system, internalization, aqidah, morality, learning

\section{A. Pendahuluan}

Secara filosofis, nilai sangat terkait dengan masalah etika. Etika juga sering disebut sebagai filsafat nilai, yang mengkaji nilainilai moral sebagai tolok ukur tindakan dan perilaku manusia dalam berbagai aspek kehidupannya. Sumber-sumber etika dan moral bisa merupakan hasil pemikiran, adat istiadat atau tradisi, ideologi bahkan dari agama. Dalam konteks etika dalam Pendidikan Islam maka sumber etika dan nilai-nilai yang paling shahih adalah al-Qur'an dan Sunnah Nabi Saw, yang kemudian dikembangkan oleh hasil ijtihat para ulama. Nilai-nilai yang bersumber kepada adat istiadat atau tradisi dan ideologi sangat rentan dan situasional. Sebab keduanya adalah produk budaya manusia yang bersifat relatif, kadang-kadang bersifat lokal dan situasional. Sedangkan nilai-nilai Qur'ani, yaitu nilai yang bersumber kepada al-Qur'an adalah kuat dan tidak relatif, karena ajaran al-Qur'an bersifat mutlak dan universal.

Ditinjau dari sudut pandang sosiologis dan antropologis, fungsi utama pendidikan adalah untuk menumbuhkan kreatifitas peserta didik, dan menanamkan nilai yang baik. Karena itu tujuan akhir pendidikan adalah untuk mengembangkan potensi kreatif peserta didik agar menjadi manusia yang baik, menurut pandangan manusia dan Allah SWT.

Persoalan manusia baik adalah persoalan nilai, tidak hanya persoalan fakta dan kebenaran ilmiah rasional. Akan tetapi menyangkut masalah penghayatan dan pemaknaan yang lebih bersifat efektif dari pada kognitif. Untuk mencapai tujuan menjadikan manusia, dibutuhkan materi pendidikan yang baik, tujuan yang baik, strategi, pendekatan, metode dan teknik belajar mengajar yang baik pula. Persoalan menjadikan manusia baik, tidak hanya menjadi persoalan pendidikan, melainkan juga menjadi tanggung jawab semua jenis pendidikan, baik pendidikan rasional, teknologi, ekonomi, maupun pendidikan jasmaniah. 
Kewajiban mengimplikasikan nilai dalam semua jenis pendidikan, sebenarnya merupakan konsekuensi logis dari tujuan pendidikan untuk menjadikan manusia baik. Sehingga pendidikan IPTEK harus mampu melahirkan cendekiawan, ilmuwan, dan teknokrat yang ahli dalam bidang masing-masing sekaligus peduli terhadap tata nilai yang hidup dalam kenyataan masyarakat sekitar, memiliki tanggung jawab sosial, dan landasan kepribadian yang kuat.

Sasaran pengajaran aqidah adalah untuk mewujudkan maksud-maksud sebagai berikut:

a. Memperkenalkan kepada murid kepercayaan yang benar yang menyelamatkan mereka dari siksaan Allah, juga memperkenalkan tentang rukun iman, taat kepada Allah dan beramal dengan baik untuk kesempurnaan iman mereka

b. Mananamkan dalam jiwa anak beriman kepada Allah, malaikat, Kitab-kitab Allah, Rasul-rasaulNya tentang hari kiamat.

c. Menumbuhkan generasi yang kepercayaan dan keimanannya sah dan benar, yang selalu ingat kepada Allah, bersyukur dan beribadah kepadaNya.

d. Membantu murid agar berusaha memahami berbagai hakekat misalnya:

1) Allah berkuasa dan mengetahui segala sesuatu. Percaya bahwa Allah adil, baik di dunia maupun di akhirat

2) Membersihkan jiwa dan pikiran murid dari perbuatan syirik (Ahmad, 1985: 121-122)

Namun pendidikan yang berwawasan nilai tidak harus mengorbankan kreatifitas rasional dan ketrampilan tinggi bagi peserta didik, yang terjadi sebaliknya, pendidikan nilai dapat mempergunakan pendekatan rasional ilmiah.

Membahas mengenai masalah nilai, termasuk nilai kemanusiaan dan ketuhanan tidak sederhana. Sebab selain pendekatan yang digunakan menggunakan pendekatan rasional dan efektif, juga didasarkan atas nilai yang bersifat normatif. Di samping itu arti baik itu sendiri sangat bervariasi sesuai dengan konteks kalimat dan sifat obyek yang dijelaskan.

Tujuan yang baik, tidak sama pengertiannya dengan materi yang baik, dan manusia yang baik. Manusia yang baik adalah manusia 
yang memiliki kepribadian utama; tujuan yang baik adalah tujuan yang dapat dijangkau, dan memiliki dimensi yang luas. Adapun materi yang baik adalah materi yang sesuai dengan pemikiran peserta didik.

Pendidikan akhlaq berkisar tentang persoalan kebaikan dan kesopanan, tingkah laku yang terpuji serta berbagai persoalan yang timbul dalam kehidupan sehari-hari dan bagaimana seharusnya seorang siswa betingkah laku. Pendidikan akhlaq yang didasarkan pada ayat-ayat Al-Qur'an dan Hadits rasul serta memberi contohcontoh yang baik harus diikuti. Allah tidak akan memerintahkan kepada mereka kecuali hal-hal yang baik dan tidak akan melarang mereka kecuali hal-hal yang buruk.

Islam sangat mementingkan pendidikan rohani dan membersihkan jiwa dari kedengkian, penipuan, kemunafikan dan buruk sangka terhadap seseorang tanpa sebab. Jiwa yang kokoh tidak mungkin dapat dicacapi kecuali dengan takut kepada Allah yaitu menanam aqidah yang benar dan pendidikan akhlaq. Oleh karena itu, guru harus membimbing siswa berakhlakul karimah dengan beberapa contoh diantaranya contoh teladan yang baik, karena keteladanan akan memberi pengaruh yang besar terhadap pendidikan akhlaq siswa. Disamping keteladanan, pengajaran akhlaq juga dapat dilakukan dengan menggunakan metode cerita.

\section{B. Pembahasan}

Nilai adalah suatu seperangkat keyakinan atau perasaan yang diyakini sebagai suatu identitas yang memberikan corak yang khusus kepada pola pemikiran, perasaan, keterikatan, maupun perilaku. Oleh karena itu sistem nilai dapat merupakan standar umum yang diyakini, yang diserap dari keadaan objektif maupun diangkat dari keyakinan sentiment (perasaan umum), maupun identitas yang diberikan kejadian umum, identitas umum yang oleh karenanya menjadi syariat umum. Sistem nilai adalah merupakan ketentuan umum yang merupakan pendekatan kepada hakikat filisofi dari ketiga hal tersebut di atas (keyakinan, sentiment, dan identitas).

Menurut Djahiri (1996: 17), nilai adalah harga yang diberikan oleh seseorang atau sekelompok orang terhadap sesuatu (materiil, immateriil, personal atau kondisional) atau harga yang dibawakan 
tersirat atau menjadi jati diri dari sesuatu. Pengertian tersebut menunjukkan bahwa sifat melekat pada sesuatu (sistem kepercayaan) yang telah berhubungan dengan subyek yang memberi arti yakni manusia yang meyakini. Selain itu, jelas adanya hubungan antar subjek penilaian dengan objek, namun demikian nilai-nilai sematamata terletak kepada subjek pemberi nilai, tetapi di dalam sesuatu tersebut mengandung hal yang bersifat esensial yang menjadikan sesuatu itu bernilai.Menurut Kattosf (1987: 328-329), nilai diartikan sebagai berikut:

1. Nilai merupakan kualitas empiris yang tidak dapat didefinisikan, tetapi kita dapat mengalami dan memahami secara langsung kualitas yang terdapat dalam objek itu. Dengan demikian nilai tidak semata-mata subjektif, melainkan ada tolok ukur yang pasti yang terletak pada esensi objek itu.

2. Nilai sebagai objek dari suatu kepentingan, yakni suatu objek yang berada dalam kenyataan maupun pikiran dan dapat memperoleh nilai jika suatu ketika berhubungan subjek-subjek yang memiliki kepentingan.

3. Nilai adalah sebagai hasil dari pemberian nilai, nilai itu diciptakan oleh situasi kehidupan.

4. Nilai sebagai esensi nilai adalah hasil ciptaan yang sudah ada sejak semula, terdapat dalam setiap kenyataan namun tidak bereksistensi, nilai itu bersifat objektif dan tetap.

Dari pengertian tersebut, nilai merupakan esensi yang melekat pada sesuatu yang sangat berarti bagi kehidupan manusia. Adapun definisi aqidah akhlaq sebelum mengenal dan menganalisa beberapa terminologi aqidah (al-musthalahat al-aqadiyah), adalah penting untuk mendefinisikan terlebih dahulu kata al-mushtashalahat al'aqadiyah. Ada beberapa terminologi aqidah; yang pertama adalah aqidah. Kata aqidah telah melalui tiga tahap perkembangan makna. Tahap pertama, aqidah diartikan dengan: 1) tekad yang bulat (al'azm al-Muakkad), 2) mengumpulkan (al-jam'u), 3) niat (an-niyah), 4) menguatkan perjanjian (at-tautsiq lil 'uqud), 5) sesuatu yang diyakini dan dianut oleh manusia, baik itu benar atau salah

Tahap kedua, perbuatan hati. Disinilah aqidah mulai diartikan sebagai perbuatan hati sang hamba. Makna ini lebih sempit dari tahap 
sebelumnya. Dari sinilah kemudian aqidah didefinisikan sebagai keimanan yang tidak mengandung kontrak. Makna ini dapat dianggap sebagai makna yang syar'i.

1) kata iman disini berarti pembenaran

2) kata aqidah tidak mengandung kontrak, berarti tidak ada sesuatu selain iman dalam hati sang hamba, tidak ada asumsi selain bahwa ia beriman kepadaNya.

Tahap ketiga, disini aqidah telah memasuki masa kematangan dimana ia telah terstrukur sebagai disiplin ilmu dengan ruang lingkup permasalahan tersendiri.

Adapun aqaid adalah jama' dari aqidah artinya kepercayaan. Menurut syara' kepercayaan ('aqidah) ialah iman yang kokoh terhadap segala sesuatu yang disebut secara tegas dalam alQur'an dan Hadits ada tiga sendi aqidah islamiyah yaitu:

a. Ketuhanan, meliputi sifat-sifat Allah SWT, nama-namaNya yang baik dan segala pekerjaannya.

b. Kenabian (nubuwwah), meliputi sifat-sifat nabi, keterpeliharaan mereka dalam menyampaikan risalah mereka, beriman tentang kerasulan dan mu'jizat yang diberikan kepada mereka, dan beriman dengan kitab-kitab yang diturunkan Allah kepada mereka.

c. Yang didengar meliputi:

1) Alam rohani, membahas tentang alam yang tak dapat dilihat dengan mata.

2) Alam barzakh, kehidupan dalam alam kubur sampai bangkit pada hari kiamat

3) Kehidupan di alam akhirat, meliputi tanda-tanda kiamat, hura-hura, pembalasan amal perbuatan dan lain-lain.

Sebagian ulama fiqh mendefinisikan aqidah ialah sesuatu yang diyakini dan dipegang teguh, sukar sekali dirubahnya. Ia beriman sesuai dengan dalil-dalil yang sesuai dengan kenyataan, seperti beriman kepada Allah SWT, hari kiamat, kitab-kitab Allah, kepada para malaikatNya dan kepada qada' qadar.

Kepercayaan itu tumbuh karena adanya dalil-dalil yang dapat diterima akal sehat. Melihat bintang, matahari, bulan, malam, siang, 
angin, hujan dan seluruh isi alam ciptaan Allah manjadi dalil yang kuat bahwa alam ini ada penciptanya.

Kata aqidah dalam bahasa Arab atau dalam Bahasa Indonesia ditulis akidah menurut terminologi berarti ikatan, sangkutan. Disebut demikian karena ia mengikat dan menjadi sangkutan atau gantungan segala sesuatu. Dalam pengertian teknis artinya adalah iman atau keyakinan. Akidah Islam (aqidah islamiyah), karena itu, ditautkan dengan rukun iman yang menjadi asas seluruh ajaran Islam. Kedudukannya sangat fundamental, karena menjadi asas sekaligus menjadi gantungan segala sesuatu dalam Islam.

Akidah Islam berawal dari keyakinan kepada Zat Mutlak Yang Maha Esa yaitu Allah. Allah Maha Esa dalam zat, sifat, perbuatan dan wujud-Nya. Kemahaesaan Allah dalam zat, sifat, perbuatan dan wujudNya itu disebut Tauhid. Tauhid menjadi inti rukun iman dan prima causa seluruh keyakinan Islam. Secara sederhana, sistematika akidah Islam, dapat dijelaskan sebagai berikut. Kalau orang telah menerima tauhid sebagai prima causa yakni asal yang pertama, asal dari segala-galanya dalam keyakinan Islam, maka rukun iman yang lain hanyalah akibat logis (masuk akal) saja penerimaan tauhid tersebut. Kalau orang yakin bahwa (1) Allah mempunyai kehendak, sebagai bagian dari sifat-Nya, maka orang yakin pula adanya (para) (2) Malaikat yang diciptakan Allah (melalui perbuatan-Nya) untuk melaksanakan dan menyampaikan kehendak Allah yang dilakukan oleh malaikat Jibril kepada para Rasul-Nya, yang kini dihimpun dalam (3) Kitab-kitab Suci.

Namun, perlu segera dicatat dan diingat bahwa kitab suci yang masih murni dab asli memuat kehendak Allah, hanyalah alQur'an. Kehendak Allah itu disampaikan kepada manusia melalui manusia pilihan Tuhan yang disebut Rasulullah atau UtusanNya. Konsekuensi logisnya adalah kita meyakini pula adanya para (4) Rasul yang menyampaikan dan menjelaskan kehendak Allah kepada umat manusia, untuk dijadikan pedoman dalam hidup dan kehidupan. Hidup dan kehidupan ini pasti akan berakhir pada suatu ketika, sebagaimana dinyatakan dengan tegas oleh kitab-kitab suci dan oleh para rasul itu. Akibat logisnya adalah kita yakin adanya (5) Hari Akhir, tatkala seluruh hidup dan kehidupan seperti yang ada sekarang ini akan berakhir. Pada waktu itu kelak Allah Yang Maha 
Esa dalam perbuatan-Nya itu akan menyediakan suatu kehidupan baru yang sifatnya baqa (abadi) tidak fana (sementara) seperti yang kita lihat dan alami sekarang. Untuk mendiami alam baka itu kelak, manusia yang pernah hidup di dunia ini, akan dihidupkan kembali oleh Allah Yang Maha Esa dalam perbuatan-perbuatan-Nya itu dan akan dimintai pertanggungan jawab individual mengenai keyakinan (akidah), tingkah laku (syari'ah) dan sikap (akhlak)-nya selam hidup di dunia yang fana ini. Yakin akan adanya hidup lain selain kehidupan sekarang, dan dimintainya pertanggungan jawab manusia kelak, membawa konsekuensi pada keyakinan akan adanya (6) Qada dan Qadar yang berlaku dalam hidup dan kehidupan manusia di dunia yang fana ini yang membawa akibat pada kehidupan di alam baka kelak.

Akhlaq dalam Bahasa Indonesia berasal dari bahasa Arab akhlaq bentuk jamak kata khuluq atau al-khulq, yang secara etimologi antara lain berari budi pekerti, perangai, tingkah laku atau tabiat (Djatmika, 1987: 25). Dalam kepustakaan, akhlak diartikan juga dengan sikap yang melahirkan perbuatan (perilaku, tingkah laku) mungkin baik, mungkin buruk, seperti disebut di atas.

Budi pekerti, perangai atau tingkah laku kita ketahui maknanya dalam percakapan sehari-hari. Namun, agar lebih jelas, tidak ada salahnya kalau dituliskan juga diantara uraian disini. Budi pekerti dari bahasa Sansekerta yang artinya tingkah laku, perangai dan akhlak atau kelakuan. Baik budi pekerti maupun perangai dalam pelaksanaannya bisa berwujud tingkah laku positif dan bisa juga tingkah laku negatif. Tingkah laku positif diantaranya adalah perangai atau tabiat yang sifatnya benar, amanah, sabar, pemaaf, pemurah, rendah hati dan lainlain sifat yang baik. Sedang yang termasuk akhlak atau budi pekerti yang negatif atau buruk adalah semua tingkah laku, tabiat, watak, perangai sombong, dendam, dengki, khianat dan lain-lain sifat yang buruk.

Akhlak islami, adalah keadaan yang melekat pada jiwa manusia. Karena itu perbuatan baru dapat disebut pencerminan akhlak jika memenuhi beberapa syarat, antara lain;

1) Dilakukan berulang-ulang, jika diakukan sekali saja tidak dapat disebut akhlak. 
2) Timbul dengan sendirinya, tanpa pikir-pikir atau ditimbangtimbang berulang-ulang karena perbuatan itu telah menjadi kebiasaan baginya.

Akhlak menempati posisi yang sangat penting dalam Islam. Ia dengan takwa, yang akan dibicarakan nanti, merupakan 'buah' pohon Islam yang berakarkan akidah, bercabang dan berdaun syariah. Pentingnya kedudukan akhlak, dapat dilihat dari berbagai sunnah qauliyah (sunnah dalam bentuk perkataan) Rasulullah. Di antaranya adalah,"Sesungguhnya aku diutus untuk menyempurnakan akhlak" (Hadis Rawahu Ahmad); "Mukmin yang paling sempurna imannya adalah orang yang paling baik akhlaknya" (H.R. Tarmizi). Dan, akhlak Nabi Muhammad, yang diutus menyempurnakan akhlak manusia itu, disebut akhlak Islam atau akhlak Islami, karena bersumber dari wahyu Allah yang kini terdapat dalam al-Qur'an yang menjadi sumber utama agama dan ajaran Islam.

Selain dengan kata-kata tersebut dalam Kamus Bahasa Indonesia (2008: 28), perkataan akhlak sering juga disamakan dengan budi pekerti; tabiat; kelakuan; watak. Bahkan, supaya kedengarannya lebih 'modern' dan 'mendunia', perkataan akhlak, budi pekerti dan lainlain itu, kini, sering diganti dengan kata moral dan etika. Penggantian itu sah-sah saja dilakukan, asal saja orang mengetahui dan memahami perbedaan arti kata-kata dimaksud.

\section{Sumber Utama Pendidikan Penanaman Sistem Nilai}

Secara filosofis, nilai sangat terkait dengan masalah etika. Etika juga sering disebut sebagai filsafat nilai, yang mengkaji nilainilai moral sebagai tolok ukur tindakan dan perilaku manusia dalam berbagai aspek kehidupannya. Sumber-sumber etika dan moral bisa merupakan hasil pemikiran, adat istiadat atau tradisi, ideologi bahkan dari agama. Dalam konteks etika dalam Pendidikan Islam maka sumber etika dan nilai-nilai yang paling shahih adalah al-Qur'an dan Sunnah Nabi Saw, yang kemudian dikembangkan oleh hasil ijtihat para ulama. Nilai-nilai yang bersumber kepada adat istiadat atau tradisi dan ideologi sangat rentan dan situasional. Sebab keduanya adalah produk budaya manusia yang bersifat relatif, kadang-kadang bersifat lokal dan situasional. Sedangkan nilai-nilai Qur'ani, yaitu nilai yang bersumber kepada al-Qur'an adalah kuat dan tidak relatif, karena ajaran al-Qur'an bersifat mutlak dan universal. 
Poin utama pembahasan ini adalah untuk mencari upaya yang sungguh-sungguh agar Pendidikan Islam menjadi pilihan utama bagi masyarakat dalam mencerdaskan kehidupan bangsa. Pencerdasan akal pikiran dan sekaligus pencerdasan hati (Qalbu) merupakan langkah yang sangat efektif dalam membangun bangsa saat ini, maka memerlukan generasi-generasi yang memiliki kecerdasan intelektual dan cerdas Qalbunya kedua kecerdasan ini hanya akan diperoleh bilamana lembaga pendidikan menggali dan menyelami nilai-nilai yang diajarkan al-Qur'an dalam membangun kualitas Sumber Daya Umat (SDU) yang berkualitas dengan cara mengaktualisasikan nilainilai Qur'ani dalam sistem Pendidikan Islam.

Sesuai dengan terminologi diatas, maka sumber nilai dapat disimpulkan:

a. Nilai yang Ilahi: yaitu al-Qur'an dan Sunnah

b. Nilai yang mondial (duniawi), ra'yu (pikiran), adat istiadat dan kenyataan alam.

Bagi umat Islam sumber nilai yang tidak berasal dari al-Qur'an dan Sunnah itu boleh digunakan sepanjang tidak menyimpang atau yang menunjang sistem nilai yang bersumber kepada al-Qur'an dan Sunnah. Untuk lebih jelasnya maka dapat diberikan contoh sebagai berikut:

1) Nilai yang berasal dari al-Qur'an: misal shalat, zakat, puasa, haji dan sebagainya.

2) Nilai yang berasal dari Sunnah yang hukumnya wajib: misal tata pelaksanaan thaharah, tata pelaksanaan shalat dan sebagainya.

3) Nilai yang berasal dari ra'yu: memberikan penafsiran dan penjelasan terhadap al-Qur'an dan Sunnah, hal yang berhubungan dengan kemasyarakatan yang tidak diatur oleh al-Qur'an dan al-Sunnah, dan sebagainya.

4) Nilai yang bersumber kepada adat istiadat: tata cara komunikasi, interaksi sesama manusia dan sebagainya.

5) Nilai yang bersumber kepada kenyataan alam: tata cara berpakaian, tata cara makan dan sebagainya.

2. Tujuan Pendidikan Penanaman Sistem Nilai

Secara umum tujuan pendidikan nilai-nilai ketuhanan dan nilai-nilai kemanusiaan adalah agar supaya siswa dapat memiliki 
dan meningkatkan terus-menerus nilai-nilai iman dan taqwa kepada Tuhan Yang Maha Esa sehingga dengan pemilikan dan peningkatan nilai-nilai tersebut dapat menjiwai tumbuhnya nilainilai kemanusiaan yang luhur, Nilai-nilai kemanusiaan yang luhur adalah nilai-nilai ilmu pengetahuan, keindahan, kejasmanian, kemasyarakatan, dan nilai-nilai politik yang dijiwai oleh nilai-nilai ilahiyah yang bersifat universal dan abadi yang berlaku bagi segenap manusia yang tidak terbatas kepada ruang dan waktu. Nilai-nilai yang tidak luhur tidak sepantasnya dikembangkan dalam pendidikan walaupun hal ini ada dalam kenyataan hidup pada masyarakat.

Sedangkan tujuan pendidikan nilai-nilai ketuhanan dan kemanusiaan secara khusus dapat dirumuskan sebagai berikut:

a. Tujuan khusus pendidikan nilai-nilai ketuhanan adalah:

1) Untuk meningatkan ketaqwaan kepada Tuhan Yang Maha Esa.

2) Untuk menginternalisasikan nilai-nilai ke-Tuhanan sehingga dapat menjiwai lahirnya nilai-nilai etik insani.

b. Tujuan khusus pendidikan nilai ilmu pengetahuan adalah:

1) Untuk menanamkan sikap menghargai kebenaran dan menjunjung tinggi kebenaran

2) Untuk menanamkan sikap gemar terhadap ilmu dan mau mengembangkan ilmu pengatahuan dan teknologi dalam mewujudkan kesejahteraan manusia.

c. Tujuan khusus pendidikan keindahan adalah:

1) Untuk menanamkan sikap menghargai seni budaya yang tidak bertentangan dengan nilai-nilai ilahiyah dan insaniyah

2) Untuk menumbuhkan sikap yang apresiatif bidang seni budaya.

d. Tujuan khusus pendidikan nilai kejasmanian adalah untuk:

1) Menanamkan pendidikan kesehatan badan

2) Untuk menanamkan nilai-nilai dan sikap mental yang sportif dan jujur.

e. Tujuan khusus pendidikan nilai kemasyarakatan adalah:

1) Untuk menanamkan sikap dan nilai kebersamaan sosial.

2) Untuk membantu siswa dalam menyesuaikan diri dengan nilai-nilai sosial kemasyarakatan. 
f. Tujuan khusus pendidikan nilai-nilai politik adalah untuk:

1) Menanamkan kesadaran berpolitik.

2) Menanamkan kesadaran tanggung jawab sosial melalui kekuaaan politik.

Tujuan Pendidikan Sistem Nilai jika ditinjau dari sifat Qur'ani sesuai dengan perkembangan masyarakat yang semakin dinamis sebagai akibat kemajuan ilmu dan teknologi, terutama teknologi informasi, maka akulturasi nilai-nilai al-Qur'an menjadi sangat penting. Karena tanpa akulturasi kitab suci ini, umat Islam akan menghadapi kendala dalam upaya internalisasi nilai-nilai Qur'ani sebagai upaya pembentukan pribadi umat yang beriman, bertaqwa, berakhlak mulia, cerdas, maju, dan mandiri. Secara normatif, tujuan yang ingin dicapai dalam proses akulturasi nilai-nilai al-Qur'an dalam pendidikan meliputi tiga dimensi atau aspek kehidupan yang harus dibina dan dikembangkan oleh pendidikan yaitu:

Pertama dimensi spiritual, yaitu iman, taqwa, dan akhlak mulia yang tercemin dalam ibadah dan mu'amalah. Dimensi spiritual ini tersimpul dalam satu kata yaitu akhlak. Akhlak merupakan alat kontrol psikis dan sosial bagi individu dan masyarakat. Tanpa akhlak manusia akan berbeda dengan kumpulan hewan dan binatang yang tidak memiliki tata nilai dalam kehidupannya. Rasulullah saw merupakan sumber akhlak yang hendaknya diteladani oleh orang mukmin, seperti sabdanya,"Sesungguhnya aku diutus tidak lain untuk menyempurnakan akhlak yang mulia".

Kedua dimensi budaya, yaitu kepribadian yang mantap, mandiri, tanggung jawab, kemasyarakatan, dan kebangsaan. Dimensi ini secara universal menitikberatkan pada pembentukan kepribadian muslim sebagai individu yang diarahkan kepada peningkatan dan pengembangan faktor dasar (bawaan) dan faktor ajar (lingkungan), dengan berpedoman kepada nilainilai keislaman. Faktor dasar dikembangkan dan ditingkatkan kemampuan melalui bimbingan dan pembiasaan berpikir, bersikap, dan bertingkah laku menurut norma-norma Islam. Sedangkan faktor ajar dilakukan dengan cara mempengaruhi individu melalui proses dan usaha membentuk kondisi yang mencerminkan pola kehidupan yang sejalan dengan norma-norma Islam seperti teladan, nasehat, anjuran, ganjaran, 
pembiasaan, hukuman, dan pembentukan lingkungan serasi.

Ketiga dimensi kecerdasan yang membawa kepada kemajuan, yaitu cerdas, kreatif, terampil, disiplin, etos kerja, profesional, inovatif, dan produktif. Dimensi kecerdasan dalam pandangan psikologi merupakan sebuah proses yang mencakup tiga proses yaitu analisis, kreatifitas dan praktis. Kecerdasan apapun bentuknya, baik IQ/ISQ dan lain-lain saat ini diukur dengan tes-tes prestasi di sekolah, dan bukan merupakan prestasi di dalam kehidupan. Dulu kecerdasan itu diukur dengan membandingkan usia mental dengan usia kronologis, tetapi saat ini tes IQ membandingkan penampilan individu dengan ratarata bagi kelompok dengan usia yang sama. Tegasnya dimensi kecerdasan ini berimplikasi bagi pemahaman nilai-nilai al-Qur'an dalam pendidikan.

\section{Macam-Macam Nilai}

Nilai dapat dilihat dari berbagai sudut pandang yang menyebabkan terdapat bermacam-macam nilai:

a. Dilihat dari segi kehidupan manusia, nilai dapat dikelompokkan menjadi: 1)nilai biologis, 2) nilai keamanan, 3) nilai cinta kasih, 4) nilai harga diri

b. Jika dilihat dari kemampuan manusia nilai dapat dibedakan menjadi:

1) nilai yang statis: seperti kognisi, afeksi (emosi), dan psikomotor

2) nilai yang bersifat dinamis : seperti motivasi berprestasi, motivasi beraviliasi, motivasi berkuasa.

c. Nilai jika dilihat dari pendekatan proses budaya dikelompokkan dalam tujuh jenis yakni: 1) nilai ilmu pengetahuan, 2) nilai ekonomi, 3) nilai keindahan, 4) nilai politik, 5) nilai keagamaan, 6) nilai kekeluargaan, 7) nilai kejasmanian.

Pembagian nilai-nilai ini dari segi ruang lingkup hidup manusia sudah memadahi sebab mencakup hubungan manusia dengan Tuhan, hubungan manusia dengan manusia, dan hubungan manusia dengan dirinya sendiri. Karena itu nilai ini juga mancakup nilai-nilai Ilahiyah (ke-Tuhanan) dan nilai-nilai insaniyah (kemanusiaan).

a. Nilai didasarkan atas sifat nilai, dapat dibagi menjadi: 1) nilainilai subjektif, 2) nilai-nilai objektif rasional, dan 3) nilai-nilai 
objektif metafisik.

b. Nilai bila dilihat dari sumbernya terdapat 1) nilai Ilahiyah (ubudiyah dan muamalah), 2) nilai Insaniyah.

c. Dilihat dari segi hakekatnya nilai dapat dibagi menjadi: 1) nilai hakiki, 2) nilai instrumental.

\section{Metode dan Strategi Pendidikan Penanaman Sistem Nilai dalam Pembelajaran Aqidah Akhlaq}

Ada beberapa metode untuk pendidikan nilai yang sesuai dengan strategi dan pendekatan pendidikan nilai yaitu: a) metode dogmatic, b) metode deduktif, c) metode induktif, d) metode reflektif.

\section{a. Metode dogmatik}

Metode ini merupakan metode untuk mengajarkan nilainilai kepada siswa dengan jalan menyajikan nilai-nilai kebaikan dan kebenaran yang harus diterima apa adanya dan tidak boleh mempersoalkan hakikat kebenaran itu. Sehingga metode ini bisa dikatakan lemah karena metode ini tidak mampu mengembangkan kesadaran rasional siswa dalam menghayati dan memahami nilainilai kebenaran. Dan juga metode ini tidak sesuai lagi dengan taraf perkembangan berpikir anak, dan tidak cocok pula dengan hakikat nilai-nilai kebenaran agama Islam, apalagi untuk mencapai tujuan pendidikan nilai dalam agama Islam yang bertujuan menumbuhkan kesadaran pribadi tentang nilai-nilai kebenaran itu. Sehingga metode ini jarang diterapkan pada peserta didik bahkan tidak digunakan sama sekali.

\section{b. Metode deduktif}

Adalah cara menyajikan kebenaran nilai-nilai ketuhanan dan nilai-nilai kemanusiaan dengan jalan menguraikan konsepsi tentang kebenaran itu untuk difahami siswa. Metode ini mempunyai kelebihan pada anak-anak yang masih belajar nilai pada tahap pemula, karena anak tersebut terlebih dahulu dikenalkan beberapa teori tentang nilai secara umum baru kemudian ditarik rincian yang lebih sempit dan mendetail serta dihubungkan dengan kasus-kasus yang terjadi dalam masyarakat. Metode ini ada baiknya untuk mengembangkan pendidikan nilai ketuhanan dan nilai-nilai kemanusiaan. 


\section{c. Metode induktif}

Metode ini merupakan kebalikan dari metode deduktif. Dalam mengajarkan nilai kepada peserta didik mulai dari mengenalkan kasus-kasus menyatakan hidup sehari-hari, kemudian peserta didik diajak untuk menganalisis dan mengambil kesimpulan tentang mana nilai-nilai yang baik dan benar, kemudian dikembangkan. Metode ini dapat digunakan untuk pendidikan nilai bagi peserta didik yang sudah mampu diajak berfikir abstrak. Sehingga mereka mampu melakukan kajian dan analisis dar kasus konkrit, kemudian dibuat kesimpulan yang bersifat abstrak. Kekurangan dari metode ini adalah apabila dalam berbagai kasus yang serupa tetapi dalam kenyataan terdapat nilai yang bersifat kontradiktif, sehingga menyulitkan peserta didik untuk mengambil kesimpulan atau pendidik menawarkan beberapa kasus yang berbeda-beda namun memiliki nilai yang hampir sama. Karena itu dalam mempergunakan metode ini untuk pendidikan nilai, harus menjaga konsistensi penggunaan kriteria pada kasus yang serupa.

\section{d. Metode refleksi}

Metode ini merupakan gabungan dari penggunaan metode deduktif dan induktif. Yakni mengajarkan nilai dengan jalan membalik antara memberikan konsep umum kemudian menerapkannya dalam praktik kehidupan sehari-hari, atau dari melihat kasus kemudian mempelajari sistemnya. Metode ini baik untuk peserta didik yang telah memiliki kemampuan berpikir abstrak, sekaligus yang memiliki bekal teori tentang nilai yang cukup. Pemaksaan metode ini dapat digunakan untuk mengatasi kekurangan pada metode deduktif, yang kadang-kadang mengabaikan unsur empirik. Sekaligus mengatasi kelemahann penggunaan metode induktif yang terlalu berorientasi pada hal-hal yang empiric, yang kadang-kadang mengabaikan unsur teoritik. Dengan demikian metode refleksi ini merupakan metode yang paling tepat dipergunakan untuk melakukan pendidikan nilai keagamaan. Terutama bagi mahasiswa yang telah mampu berpikir secara abstrak dan mampu berpikir secara analisis. Sebagai konsekuensi penggunaan metode ini, pendidik harus benar-benar menguasai teori-teori secara umum tentang nilai-nilai kebenaran, dan dituntut memiliki daya penalaran yang tinggi untuk mengembalikan setiap kasus dalam jajaran konsepsi sistem nilai. Dari keempat metode 
tersebut di atas, metode dogmatic kurang tepat diterapkan pada pendidikan keagamaan. Adapun metode lainnya dapat dipergunakan dari variasi penggunaan metode bantu, atau menggunakan metode yang keempat.

\section{Strategi dan Pendekatan Pendidikan Nilai}

Model-model strategi pendidikan nilai diantaranya ialah:

\section{a. Strategi tradisional}

Strategi tradisional ini adalah dengan jalan memberikan nasehat atau indoktrinasi. Strategi ini ditempuh dengan jalan memberitahukan secara langsung nilai-nilai mana yang baik dan yang kurang baik.

\section{b. Strategi Bebas}

Strategi ini merupakan kebalikan dari strategi tradisional, yakni seorang guru/pendidik tidak memberitahukan kepada anak didik tentang nilai-nilai yang baik dan buruk, tetapi pendidik memberikan kebebasan sepenuhnya kepada anak untuk memilih dan menentukan nilai yang akan diambilnya.

\section{c. Strategi Reflektif}

Strategi ini merupakan cara untuk mendidik siswa dalam mengenali dan memilih nilai-nilai ketuhanan dan kemanusiaan dengan jalan mondar-mandir antara menggunakan pendekatan teoritik ke pendekatan empiric, dan mondar-mandir menggunakan pendekatan deduktif dengan induktif.

\section{d. Strategi Transinternal}

Strategi ini merupakan cara untuk mengajarkan nilai dengan jalan melakukan transformasi nilai, dilanjutkan dengan transaksi dan transinternalisasi.

\section{Model-model Pendekatan Pendidikan Nilai}

Ada beberapa model pendekatan yang sesuai dengan strategi tersebut, yaitu:

\section{a. Pendekatan doktriner}

Adalah cara menanamkan nilai kepada siswa dengan jalan memberikan doktrin/tekanan bahwa yang benar itu tidak perlu dipersoalkan dan dipikirkan, tetapi cukup diterima seperti apa adanya secara bulat. 


\section{b. Pendekatan otoritatif}

Adalah pendekatan yang menggunakan cara kekuasaan, artinya nilai-nilai kebenaran, kebaikan yang datang dari orang yang memiliki otoritas (keahlian, kekuasaan) adalah pasti benar dan baik.

\section{c. Pendekatan action}

Action dipakai untuk pendekatan pendidikan nilai dengan jalan siswa dilibatkan dalam tindakan nyata atau berpartisipasi dalam kehidupan masyarakat, sehingga dengan demikian diharapkan muncul kesadaran dalam dirinya akan nilai-nilai kebaikan dan kebenaran.

\section{d. Pendekatan kharismatik}

Kharismatik sebagai pendekatan pendidikan nilai sesuai untuk strategi pendidikan yang memberi contoh artinya siswa dengan melihat dan mengamati kepribadian seseorang yang memiliki konsistensi dan keteladanan yang dapat diandalkan, akan tumbuh kesadaran untuk menerima nilai-nilai tersebut sebagai nilai yang baik dan benar.

\section{e. Pendekatan penghayatan}

Penghayatan sebagai pendekatan dalam pendidikan nilai yang dikembangkan dengan jalan melibatkan siswa dalam kegiatan empirick keseharian tetapi lebih menekankan keterlibatan aspek efektifnya dari pada aspek rasionalnya, dengan demikian siswa diharapkan tumbuh kesadaran akan kebenaran.

\section{f. Pendekatan rasional}

Untuk menanamkan kesadaran tentang nilai baik dan benar ada kalanya dimulai dari kesadaran rasional. Informasi-informasi tentang nilai baik dan benar yang masuk melalui kesadaran rasional akan diolah secara psikologis yang melahirkan sikap efektif terhadap obyek nilai tersebut. Sealiknya bila kesadaran rasionalnya menerima obyek nilai itu sebagai kebenaran, maka sikap efektifnya akan memerikan dorongan untuk menyenangi, menyetujui, dan menghargai terhadap nilai-nilai

\section{g. Pendekatan efektif}

Pendekatan nilai denagn pendekatan efektif ini adalah dengan jalan prses emosional yang diarahkan untuk menumbuhkan motivasi nilai-nilai berbuat. Nilai-nilai yang mempribadi dari pendekatan ini 
belum ten nilai-nilai yang telah terseleksi secara kritis dan filosofis, tetapi lebih banyak nilai-nilai yang diterapkan dan bekembang dalam masyarakat

\section{Simpulan}

Secara umum tujuan pendidian nilai ketuhanan dan nilai-nilai kemanusiaan adalah agar siswa dapat memiliki dan meningkatkan terus-menerus nilai-nilai iman dan taqwa kepada Tuhan Yang Maha Esa sehingga dengan pemilikan dan peningkatan nilai-nilai tesebut dapat menjiwai nilai-nilai kemanusiaan yang luhur. Sebagaimana diketahui bahwa nilai merupakan seperangkat keyakinan atau perasaan yang diyakini sebagai suatu identitas yang memberikan corak yang khusus kepada pola pemikiran, perasaan, keterikatan, maupun perilaku. Sumber utama yang dipakai dalam pendidikan pananaman sistem nilai menurut pendidikan Islam adalah al-Qur'an dan al-Sunnah, sedangkan sumber lain adalah nilai yang mondial (duniawi), ra'yu (pikiran), adat-istiadat dan kenyataan alam.

Akhlak menempati posisi yang sangat penting dalam Islam. Ia dengan takwa, merupakan 'buah' pohon Islam yang berakarkan akidah, bercabang dan berdaun syariah. Pentingnya kedudukan akhlak, dapat dilihat dari berbagai sunnah qauliyah (sunnah dalam bentuk perkataan) Rasulullah. Di antaranya adalah,"Sesungguhnya aku diutus untuk menyempurnakan akhlak" (Hadis Rawahu Ahmad);"Mukmin yang paling sempurna imannya adalah orang yang paling baik akhlaknya" (H.R. Tarmizi). Dan, akhlak Nabi Muhammad, yang diutus menyempurnakan akhlak manusia itu, disebut akhlak Islam atau akhlak Islami, karena bersumber dari wahyu Allah yang kini terdapat dalam al-Qur'an yang menjadi sumber utama agama dan ajaran Islam.

Mengingat pentingnya aqidah akhlaq dalam Islam, sehingga pendidikan sistem nilai dalam pembelajaran sangat diperlukan dalam rangka melahirkan generasi Islam yang benar-benar islami. 


\section{DAFTAR PUSTAKA}

Ahmad, Muhammad Abdul Qadir. 1985. Metodologi Pengajaran Pendidikan Agama Islam. Jakarta: Dirjen Binbaga Islam.

Al-Munawar, Said Agil Husain. 2005. Akulturasi Nilai-nilai al-Qur'an, Jakarta: Ciputat Press.

Ali, Muhammad. 1992. Pengembangan Kurikulum di Sekolah, Bandung: Sinar Baru.

An-Nahlawi, Abdurrahman. 1984. Prinsip-prinsip Dasar Metode Pendidikan Islam dalam Keluarga di Sekolah dan Masyarakat. Salatiga.

Arif, Armei. 2002. Pengantar Metodologi Pendidikan Islam.Jakarta: Ciputat Press.

Arifin, M. 1994. Ilmu Pendidikaj Islam; Suatu Tinjauan Teoritis dan Praktis Berdasarkan Pendekatan Interdisipliner. Jakarta: Bumi Aksara.

Al-Abrasy, Muhammad Athiah. 1970. Dasar-dasar Pokok Pendidikan Islam (terj.), judul asli, At-Tarbiyah al-Islamiyah, penerjemah Bustami A.Gani, Jakarta: Bulan Bintang.

Al-Ahwani, Ahmad Fuad. 1975. At-Tarbiyah fi al-Islam. Mekah: Darul Ma'arif.

Al-Syaibant, Omar Muhammad al-Toumy. 1979. Filsafat Pendidikan Islam (terj.) Jakarta: Hasan Langgulung, Bulan Bintang.

Aly, Hery Noer. 1999. Ilmu Pendidikan Islam. Jakarta: Logos. Ramayulis. 1994. Ilmu Pendidikan Islam, Jakarta: Kalam Mulia.cet.I.

Ausubel, David. 1978. Educational Psychology, A.Cognitive View, New York: Holt, Rinehart and Winston, Inc.

Bloom, Benyamin S. 1997. Taxonomy of Education Obyektives, London: Longman, Inc.

Daradjat, Zakiah. 2001. Metodologi Pengajaran Agama Islam. Jakarta: Bumi Aksara.

Djahiri, A, K. 1996. Menelusur Dunia Afektif: Pendidikan Nilai dan 
Moral. Bandung: Lab Pengajaran PMP IKIP.

Djatmika, Rahmat . 1987. Sistem Etika Islam (Akhlak Mulia). Jakarta: Pustaka Panjimas.

Gagne, Ellen. 1985. The Cognitive Paychology of School Learning. Boston: Little, Brown and Company.

Kattsoff, Louis O. 1987. Pengantar Filsafat. Yogyakarta: Tiara Wacana Yogya.

Soekamto et al., Teoti. 1997. Teori Belajar dan Model-model Pembelajaran, Jakarta: Pusat antar Universitas, Departemen PdanK.

Tafsir, Ahmad. 1994. Ilmu Pendidikan dalam Persektif Islam cet.2. Bandung: PT. Remaja Rosda Karya.

. 1995.Metodologi Pengajaran Agama Islam. Bandung: Remaja Rosdakarya.

Tim Penyusun Kamus Pusat Bahasa. 2008. Kamus Bahasa Indonesia. Jakarta: Pusat Bahasa Departemen Pendidikan Nasional.

Zuhairini dkk. 1983. Metodik Khusus Pendidikan Agama, Surabaya: Usaha Nasional, Surabaya, cet.ke-8. 